\title{
The Formation Mechanism of Social Identity Based on Knowledge Contribution in Online Knowledge Communities: Empirical Evidence from China
}

\author{
Zhichao Cheng ${ }^{1}$, Tongfei Gu ${ }^{1, *}$ and $\mathrm{Cui} \mathrm{Li}^{2}$ \\ 1 School of Economics and Management, Beihang University, Beijing 100191, China; chengzhichao@buaa.edu.cn \\ 2 School of Economics and Management, Institute of Disaster Prevention, Sanhe 065201, China; \\ licui@cidp.edu.cn \\ * Correspondence: by1708129@buaa.edu.cn or gtfzb1985601@163.com; Tel.: +86-134-2610-7361
}

Citation: Cheng, Z.; Gu, T.; Li, C. The Formation Mechanism of Social Identity Based on Knowledge Contribution in Online Knowledge Communities: Empirical Evidence from China. Sustainability 2022, 14 , 2054. https://doi.org/10.3390/ su14042054

Academic Editor: Michele Grimaldi

Received: 28 December 2021

Accepted: 8 February 2022

Published: 11 February 2022

Publisher's Note: MDPI stays neutral with regard to jurisdictional claims in published maps and institutional affiliations.

Copyright: (C) 2022 by the authors. Licensee MDPI, Basel, Switzerland. This article is an open access article distributed under the terms and conditions of the Creative Commons Attribution (CC BY) license (https:// creativecommons.org/licenses/by/ $4.0 /)$.

\begin{abstract}
Social identity is a key factor in the sustainable development of online knowledge communities (OKCs). The purpose of this research is to explore the formation mechanism of the respective social identities of lurkers and posters, based on knowledge contribution behavior. To evaluate the research model, an online survey was conducted in the WeChat group and QQ group, which yielded 469 usable questionnaire responses. Structural equation modeling was then adapted to examine the model. We found that knowledge contribution can produce social and psychological outcomes (i.e., cognitive communication, parasocial interaction, a sense of self-worth, social support, and social identity). The posters' social identity arises through the mediating effects of information support and cognitive communication, while the lurkers' social identity arises through the mediating effect of parasocial interaction. In addition, this research reveals that personalized behaviors and social identity can coexist in OKCs. Our findings may provide theoretical and practical enlightenment for managers to achieve sustainable and successful operations in OKCs.
\end{abstract}

Keywords: online knowledge community; sustainable development; social identity; knowledge contribution

\section{Introduction}

With the advent of the Web 2.0 era, the content production method has shifted from institutionalization to personalization, and every internet user has the potential to become a content producer [1]. In this process of empowering "netizens", the amount of data on the internet has exploded, causing valuable information to be potentially overshadowed by vast amounts of information noise [2]. As massive, fragmented information floods the internet, it is increasingly difficult for users to obtain the relevant information that they need [3]. Users urgently need a platform that can provide true, accurate, and professional information and knowledge. Therefore, virtual communities (VC) have emerged at this historic moment, and an online knowledge community (OKC) is one such type of VC. The OKC is a network platform whose main function is to facilitate the sharing and acquisition of knowledge among users [4]. On this platform, users with common interests gather to exchange knowledge and pursue interpersonal interaction through the internet, thereby achieving the goals of knowledge acquisition, communication, exchange, and innovation [5].

One of the primary ways for users to participate in VCs is through posting, which is also referred to as knowledge contribution. Users can be categorized into posters and lurkers, according to whether they have made knowledge contributions [6]. Posters actively participate in discussions and are willing to help others by posting, while lurkers are silent participants who usually only browse information but never participate in discussions [7]. Posters contribute to the communities by posting valuable information, while lurkers can 
also contribute to the communities by reposting information to make it easier for others to search this network platform. Therefore, the loyalty of posters and lurkers is the key to the sustainable and successful operation of OKCs [8].

Due to the anonymity and separation of geographical space, posters dare to show different opinions and say things that they would not dare to express in person or in front of acquaintances. Therefore, knowledge contribution shows a distinct personalization. Personalized knowledge contributions may cause too many quarrels, leaving the virtual community in a state of disorder. To realize or maintain orderly operations, reasonable management mechanisms for personalized behaviors are needed within VCs to avoid extreme behavior and chaos [9]. Social identity describes the process of constructing an individual's identity [10], which facilitates individuals internalizing group norms and taking ideas and behaviors shared by the group to be their own thoughts and behaviors. Therefore, social identity can generate a self-regulatory mechanism in OKCs. Social identity plays a key role in limiting excessive personalized behaviors and preventing the occurrence or further development of some excessive or irrational behaviors, so that knowledge contribution can show personalization and a certain degree of rationality and orderliness. Some studies have demonstrated empirically that the social identity of posters can be generated based on the satisfaction of social and psychological needs produced by knowledge contribution behaviors, which impacts the posters' willingness to contribute knowledge behaviors [11]. The role of a self-running mechanism is to make the OKCs run properly and develop stainability. In summary, the key to the sustainable development of OKCs lies in the establishment of group members' social identity.

Previous scholars have studied the formation mechanism of social identity by considering group members as a whole in VCs [12], but there is little research on how the respective social identities of posters and lurkers are formed in OKCs. This study profoundly explores the social and psychological outcomes of knowledge contribution behaviors and the formation mechanism of the respective social identities of lurkers and posters by constructing a model in OKCs and providing theoretical and practical enlightenment for the sustainable development of online knowledge communities.

\section{Theoretical Background}

\subsection{Knowledge Contribution}

Knowledge contribution refers to the transfer and sharing of knowledge from one person or group to another person or group. The difference between online communication and actual communication is mainly reflected in three aspects. First, there is no space limitation; the internet provides members with conditions for instant and two-way interaction [13]. The second is the diversification of the means of display. Network technology enables the integration of multiple media means, and users can communicate through text, images, videos, and other methods at the same time to acquire a strong cyberspace experience, which enables users to have a real sense of their existence in cyberspace [14]. The third is the virtual nature of self-presentation. To meet their psychological needs, users can create a virtual idealized self-image on the internet that is different from their self-image in real life [15].

Users are generally anonymous in OKCs. Due to this anonymity, posters tend to express themselves more freely, and the content expressed is bolder, richer, and truer than when they are face-to-face, so the content of knowledge contribution shows personalized characteristics. Personalized knowledge contribution can foster interpersonal interaction and determine the vitality of OKCs. Therefore, knowledge contribution plays a vital role in the successful creation and development of OKCs [16].

Many studies have reported that the motivation behind group members' knowledge contribution is mainly to meet social and psychological needs. Members can exchange opinions or conduct in-depth discussions with others on a certain issue to establish good interpersonal relationships [17]. Therefore, knowledge contribution can have social effects on members; OKCs can be characterized as goal-oriented, and members can obtain a sense 
of task completion by posting valuable information and then gain a sense of self-worth. Therefore, knowledge contribution can also have psychological effects on members [18].

\subsection{Social Identity}

Tajfel first proposed the social-psychological concept of social identity in 1972, theorizing that social identity constitutes a part of self-concept, defined as "the individual's perception of his or her identity as belonging to a particular social group, as well as the feeling and value of this identity" [19]. The generation of social identity relies on a comparison between groups, and individuals obtain a positive social identity through favorable comparisons between self-affiliated groups and external groups [20]. Based on this organizational context, Ellemers et al. (1999) reidentified the three dimensions of social identity through empirical research based on Tajfel's definition of social identity [21]: the structural dimension (behavioral performance is social interaction, indicating the familiarity and closeness of connections between group members); the relationship dimension (interpersonal relationships characterized by trust and reciprocity among group members); and the cognitive dimension (the degree of agreement between group members in terms of expression, interpretation, and understanding). The structure of social relations is regarded as a resource that can bring abundant output [22]. The structural dimension is the basic form of social capital [23], while the relationship dimension and cognitive dimension are generated based on the structural dimension in VCs.

There are two forms of social identity: self-categorization and social belonging. Ashforth and Mael adopted the theoretical perspective that "social identity constitutes a part of self-concept" as their research focus, and fully expanded it later [24]. The theory of selfcategorization explains how social categorization leads to the generation of social identity through the deindividualization of self and others [25]. Self-categorization is the cognitive dimension of social identity, referring to the cognition of similarity between oneself and other members [26]. Social belonging refers not only to the individual's perception of belonging to a group but also to the emotional connection between the individual and the group, brought about by identity-belonging [27]. Emotional connection is an important aspect of social identity that has a significant impact on members' behavior [28]. Selfcategorization is determined by the situation, may be short-lived, and, in many cases, is determined by some factors outside the individual, while social belonging is more durable and continuous and is integrated into personal emotions, so that the internalization of norms has a greater impact on the thinking and behavior of individuals [29].

Social identity plays a critically important role in promoting the stability and sustainable development of OKCs, which means a high degree of recognition for group values, goals, and norms, as well as high role-related behavioral intentions [30]. Obviously, social identity facilitates the formation of group order and enhances community vitality by promoting participation and loyalty among group members.

\section{Research Model and Hypotheses}

\subsection{Knowledge Contribution, Cognitive Communion, and Information Support}

Social interaction is a basic need for human beings. An important motivation for knowledge contribution behaviors is the desire to be understood, paid attention to, and even praised by others [31]. Satisfying this motivation can be achieved through interaction with others [32]. Knowledge contribution enables communication with others, as well as the development and maintenance of friendships, and promotes interpersonal interaction among group members [33]. Through interpersonal interaction, members can become familiar with each other and, thus, find people who share their views or ideas more easily, eliciting a sense of like-mindedness among members. The subject of interaction always revolves around topics of common interest, and knowledge contribution always attracts replies, so posters can actively answer questions posed by others in their replies [34]. Based on these findings, the following hypotheses are proposed: 
Hypothesis 1 (H1). Knowledge contribution is positively associated with cognitive communion in OKCs.

Hypothesis 2 (H2). Knowledge contribution is positively associated with information support in OKCs.

\subsection{Parasocial Interaction, Cognitive Communion and Information Support}

Parasocial interaction is a description of an interpersonal relationship that is similar to one in real life. It can be used to describe the audience's imaginary mutual understanding of and intimacy with media characters, although the audience cannot communicate directly with media characters [35]. Many studies have identified that even if members do not directly interact with others in the online context, as long as they browse the online information and perceive the presence of other participants, it is enough to trigger the sense of parasocial interaction [36]. Information support refers to members answering questions for others, reflecting the functional value of OKCs [37]. This kind of interpersonal interaction behavior, with strong pertinence and high practical value, can enhance psychological participation even more. Cognitive communication embodies the similarity of the cognitive level that an individual perceives when in the process of communicating with others. By browsing online information, lurkers can judge whether other people's views and ideas are similar to their own, and a high degree of cognitive similarity can effectively facilitate psychological interaction. Therefore, we hypothesize the following:

Hypothesis 3 (H3). Information support is positively associated with parasocial interaction in OKCs.

Hypothesis 4 (H4). Cognitive communion is positively associated with parasocial interaction in OKCs.

Hypothesis 5 (H5). Cognitive communion is positively associated with information support in OKCs.

\subsection{Cognitive Communion and Social Identity}

The degree to which individual members perceive themselves as being similar to other group members is a key factor in generating social belonging [38]. The sense of belonging brought by the perceived similar level of cognitive communication is a precondition for the formation of social identity. Social belonging refers to the way "the individual perceives the meaning of his emotion and value to the social group based on membership" [39]. Therefore, a sense of belonging is accompanied by an emotional connection with the group. Members can perceive social belonging via an inductive path and then form their own social identity. Accordingly, we propose the following:

Hypothesis 6 (H6). Cognitive communion is positively associated with social identity.

\subsection{Knowledge Contribution, Information Support, and Sense of Self-Worth}

The sense of self-worth refers to the degree to which members perceive that they are valuable and important to the group. An OKC can be thought of as a network working group formed for a task, wherein members provide their own ideas for solving a certain problem or provide solutions to other members' problems by posting [40]. The value and importance of members to the OKCs are not given in advance and can be perceived only after members have made contribution behaviors [17]. Knowledge contribution may be in the form of active posting or feedback posting, while information support is feedback posting; both contribute to OKCs. Members with knowledge contribution or information support may feel a sense of accomplishment after completing their work tasks, which can generate a sense of self-worth [41]. Thus, the following hypotheses are proposed: 
Hypothesis 7 (H7). Knowledge contribution is positively associated with the sense of self-worth in OKCs.

Hypothesis 8 (H8). Information support is positively associated with the sense of self-worth in OKCs.

\subsection{Social Identity and Sense of Self-Worth}

The sense of self-worth arises from contribution behaviors, and members who are important to the group may have a higher social identity [42]. The sense of self-worth also facilitates members in attaining a high degree of satisfaction, which could enhance members' willingness to belong to the group, thereby generating social identity [43]. Based on these findings, we propose the following:

Hypothesis 9 (H9). The sense of self-worth is positively associated with social identity in OKCs.

\subsection{Information Support and Social Identity}

Providing suggestions or solutions to problems raised by others facilitates the posters' perception of common tasks and goals, then cultivates a common and consistent understanding of the group [44]. On the basis of the work-group perspective, the formation of common tasks and goals can lead posters to view themselves and others as a whole and, thus, perceive a common social identity for the group [45]. In summary, we propose the following:

Hypothesis 10 (H10). Information support is positively associated with social identity in OKCs.

\subsection{Parasocial Interaction and Social Identity}

The more an individual participates in activities in the group, the more familiar he or she is with the group, which narrows the psychological distance and further develops their attachment to the group [46]. The social nature of OKCs implies that members can browse the posts of posters without reciprocal responsibility. Browsing information is a participation behavior that generates individual attachment to the group (i.e., group members' integration, care, and emotional attachment to the community) [47]. Thus, we hypothesize the following:

Hypothesis 11 (H11). Parasocial interaction is positively associated with social identity in OKCs.

\section{Research Methodology}

\subsection{Research Framework}

This research explores the formation mechanism of the social identity of lurkers and posters in OKCs. We discuss the relationship among knowledge contribution, parasocial interaction, cognitive communion, information support, the sense of self-worth, and social identity. Previous studies have provided a theoretical foundation for the selection of intermediate variables and model construction; we have established a research model, which is presented in Figure 1.

\subsection{Sampling and Procedure}

To examine the research model, we conducted an online questionnaire in the QQ group and WeChat group, which are affiliated with the Tencent Company. Most participants spontaneously joined several QQ groups and WeChat groups, based on a common interest or information exchange, such as the basketball group, football group, college entrance examination exchange group, and food-making group. The QQ group and WeChat group are the two most popular and widely used virtual communities in China, so data collected from these two VCs have great theoretical research value and we can extract more general findings. We obtained permission from the initiators or administrators to post a link to the 
online survey for this research. The process of data collection occurred over two months, and 469 usable responses were collected. The participants' demographic statistics are presented in Table 1.

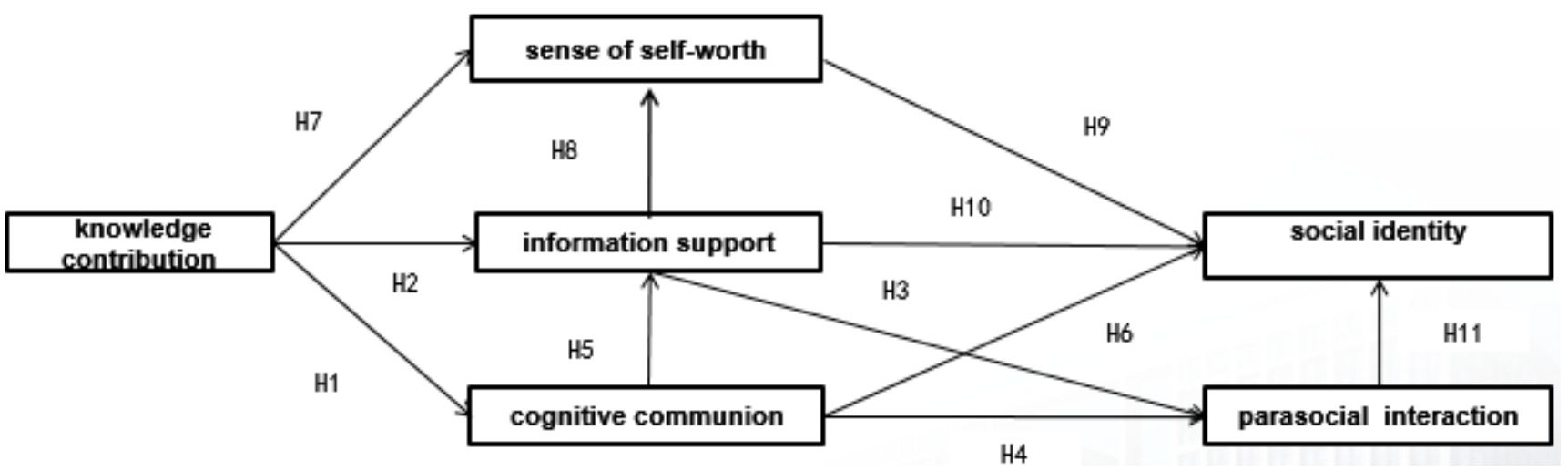

Figure 1. Research framework.

Table 1. Demographic information.

\begin{tabular}{ccc}
\hline Variables & Items & $\mathbf{( \% )}$ \\
\hline \multirow{2}{*}{ Gender } & Male & $42.6 \%$ \\
& Female & $57.4 \%$ \\
\hline \multirow{2}{*}{ Education level } & High school education and below & $26.9 \%$ \\
& Bachelor Degree & $56.7 \%$ \\
Identity & Graduate degree & $16.4 \%$ \\
\hline \multirow{2}{*}{ Age } & Student & $28.1 \%$ \\
& Worker & $71.9 \%$ \\
\hline \multirow{2}{*}{ Membership history } & $<20$ & $17.3 \%$ \\
& $21-25$ & $16.0 \%$ \\
& $26-30$ & $15.1 \%$ \\
& $31-40$ & $16.0 \%$ \\
& $>40$ & $35.6 \%$ \\
\hline \multirow{2}{*}{ More than one year and less than two years } & $30.9 \%$ \\
& More than two years & $34.8 \%$ \\
\hline
\end{tabular}

\subsection{Measures}

All survey items were modified from scales verified in previous studies. All items were measured by participants' responses to questions on a five-point Likert-type scale ranging from 1 (strongly disagree) to 5 (strongly agree). To match the specific context of this research, we have rolled out minor improvements to the wording of all items. One professor and four doctoral students in the field of online behavior pretested each survey item to guarantee logical consistency between the Chinese and the original English version of all items. The items were also previewed by students to ensure that each item in the survey was contextually relevant and understandable. All items and their standard loadings are presented in Table 2.

\subsection{Data Analyses}

AMOS 22.0 was employed to test the research model presented in Figure 1. First, the reliability and validity of the measurement model were tested with confirmatory factor analysis (CFA). Second, we adopted structural equation modeling to examine the research model. Third, the programming function of AMOS 22.0 was adopted to test the mediation effects. 
Table 2. Items and standard loadings.

\begin{tabular}{|c|c|c|}
\hline Variables & Items & Standard Loadings \\
\hline \multirow{3}{*}{$\begin{array}{l}\text { knowledge contribution } \\
\text { (adapted from [48]) }\end{array}$} & $\begin{array}{l}\text { I often share information with others in } \\
\text { this group }\end{array}$ & 0.742 \\
\hline & $\begin{array}{c}\text { I often help others solve problems in } \\
\text { this group }\end{array}$ & 0.847 \\
\hline & $\begin{array}{l}\text { The knowledge I share can often broaden } \\
\text { the horizons of other members }\end{array}$ & 0.793 \\
\hline \multirow{3}{*}{$\begin{array}{l}\text { cognitive communion } \\
\text { (adapted from [49]) }\end{array}$} & $\begin{array}{l}\text { I feel I share similar thoughts with other } \\
\text { members of the group }\end{array}$ & 0.791 \\
\hline & $\begin{array}{l}\text { I feel my knowledge is shared with other } \\
\text { members of the group }\end{array}$ & 0.750 \\
\hline & $\begin{array}{l}\text { I feel I share the same perspective as other } \\
\text { members of the group }\end{array}$ & 0.833 \\
\hline \multirow{3}{*}{$\begin{array}{l}\text { parasocial interaction } \\
\text { (adapted from [49]) }\end{array}$} & $\begin{array}{l}\text { Although I do not post, I feel like I am } \\
\text { interacting with other group members by } \\
\text { browsing the messages }\end{array}$ & 0.785 \\
\hline & $\begin{array}{c}\text { Although I do not post, I feel like I am a } \\
\text { part of the group by browsing } \\
\text { the information }\end{array}$ & 0.817 \\
\hline & $\begin{array}{l}\text { Although I do not post, I feel like I am } \\
\text { participating in the discussion with other } \\
\text { group members by browsing the messages }\end{array}$ & 0.798 \\
\hline \multirow{3}{*}{$\begin{array}{l}\text { sense of self-worth } \\
\text { (adapted from [50]) }\end{array}$} & $\begin{array}{l}\text { The knowledge I share can help other } \\
\text { members solve their problems in } \\
\text { this community. }\end{array}$ & 0.851 \\
\hline & $\begin{array}{c}\text { The knowledge I share has a positive } \\
\text { impact on this community }\end{array}$ & 0.836 \\
\hline & $\begin{array}{l}\text { By sharing my knowledge in the } \\
\text { community to help others, I become } \\
\text { more confident. }\end{array}$ & 0.800 \\
\hline \multirow{3}{*}{$\begin{array}{c}\text { social identity } \\
\text { (adapted from [51]) }\end{array}$} & $\begin{array}{l}\text { I see myself as an integral part of } \\
\text { this community }\end{array}$ & 0.741 \\
\hline & $\begin{array}{l}\text { I have a sense of belonging to } \\
\text { this community }\end{array}$ & 0.850 \\
\hline & $\begin{array}{l}\text { I feel integrated into the atmosphere of } \\
\text { this community }\end{array}$ & 0.781 \\
\hline \multirow{3}{*}{$\begin{array}{l}\text { information support } \\
\text { (adapted from [52]) }\end{array}$} & $\begin{array}{l}\text { In this group, I often provide suggestions } \\
\text { when someone needs help. }\end{array}$ & 0.773 \\
\hline & $\begin{array}{l}\text { When someone encounters a problem in } \\
\text { this group, I often give information to help } \\
\text { him or her to solve the problem }\end{array}$ & 0.833 \\
\hline & $\begin{array}{l}\text { When someone faces difficulties in this } \\
\text { group, I often help him or her to determine } \\
\text { the cause and offer him or her suggestions. }\end{array}$ & 0.808 \\
\hline
\end{tabular}

\subsection{Test for Common Method Variance}

In the survey data of this research, both the independent and dependent variables were obtained through questionnaires, and each questionnaire was completed independently by the respondents; thus, there may be a common method variance (CMV) as a result of common variance [53]. The one-factor method is one of the most widely used methods for testing CMV; hence, we adopted it to test this research model. The basic principle of this method is that if the first factor extracted by exploratory factor analysis explains more than $50 \%$ of the overall variance, it can be judged that a common method deviation exists [54]. We imported all variables into SPSS 22.0 for exploratory factor analysis, and the variance explanation rate of the first factor was $36.9 \%$, which is much smaller than the threshold value of $50 \%$. Therefore, it can be judged that CMV has little effect on this research [55]. 


\section{Results}

\subsection{Measurement Model}

The results of the measurement model performed well $(\chi 2 / \mathrm{df}=2.128, \mathrm{GFI}=0.941$, $\mathrm{AGFI}=0.916, \mathrm{CFI}=0.969, \mathrm{TLI}=0.960, \mathrm{RMSEA}=0.049)$, which suggests that the validity of this research is acceptable. Confirmatory factor analysis was employed to further examine the measurement model's construct reliability and validity. Both Cronbach's alpha and composite reliability values were employed to assess the construct reliability and validity. As displayed in Table 3, the Cronbach's $\alpha$ values ranged from 0.836 to 0.908 , and the composite reliability values ranged from 0.643 to 0.909 , which are above the acceptable level [56]. We then adopted the average variance extracted (AVE) from the constructs and factor loadings to measure convergent validity. The values of AVE from each construct are greater than 0.5, suggesting adequate convergent validity [57]. Table 2 presents the loadings of the items for the corresponding constructions. All item loadings are higher than 0.7, indicating an acceptable level [58]. As presented in Table 4, the square roots of the AVE of each construct are significantly greater than their corresponding correlation coefficients with other constructs, which verifies that this research model has significant discriminant validity.

Table 3. Cronbach's alpha, composite reliability, and AVE.

\begin{tabular}{cccc}
\hline Constructs & Cronbach's $\alpha$ & $\begin{array}{c}\text { Composite } \\
\text { Reliability }\end{array}$ & AVE \\
\hline general knowledge contribution & 0.834 & 0.837 & 0.632 \\
parasocial interaction & 0.840 & 0.842 & 0.640 \\
sense of self-worth & 0.867 & 0.868 & 0.688 \\
cognitive communion & 0.833 & 0.834 & 0.627 \\
social identity & 0.832 & 0.834 & 0.627 \\
information support & 0.846 & 0.847 & 0.648 \\
\hline
\end{tabular}

Table 4. Correlations between the latent constructs.

\begin{tabular}{ccccccc}
\hline Constructs & GKC & PI & SOS & CC & SI & IS \\
\hline general knowledge contribution (GKC) & 0.795 & & & & & \\
parasocial interaction (PI) & 0.391 & 0.800 & & & & \\
sense of self-worth (SOS) & 0.631 & 0.414 & 0.829 & & & \\
cognitive communion (CC) & 0.401 & 0.325 & 0.350 & 0.792 & & \\
social identity (SI) & 0.59 & 0.461 & 0.336 & 0.487 & 0.792 & \\
information support (IS) & 0.448 & 0.535 & 0.506 & 0.297 & 0.445 & 0.805 \\
\hline
\end{tabular}

\subsection{Structural Model}

AMOS 22.0 was adopted to test the research model. All overall-fit indices of the structural model performed well: $\chi 2 / \mathrm{df}=2.577$; GFI $=0.882 ; \mathrm{AGFI}=0.858$; $\mathrm{TLI}=0.926$; $\mathrm{CFI}=0.934$; RMSEA $=0.057$. The values of GFI, AGFI, and CFI were all higher than 0.8, while the value of RMSEA was less than 0.08, indicating an acceptable level [59]. We examined all hypotheses, and the results are presented in Figure 2.

The explained variances of parasocial interaction, sense of self-worth, cognitive communion, information support, and social identity are $33.1 \%, 47.0 \%, 18.7 \%, 41.6 \%, 23.1 \%$, and $42.6 \%$, respectively, implying that this research model has good predictive validity.

\subsection{Mediation Effects}

The multiple mediation model is presented in Figure 3. Bootstrapping is a very reasonable and powerful method for obtaining confidence limits for specific indirect effects [60]; therefore, we adopted bootstrapping to examine the multiple mediation model using AMOS 22.0. We investigated the indirect effects of knowledge contribution on social identity through the sense of self-worth, information support, cognitive communion, and 
parasocial interaction. The findings regarding these mediation effects are displayed in Table 5.

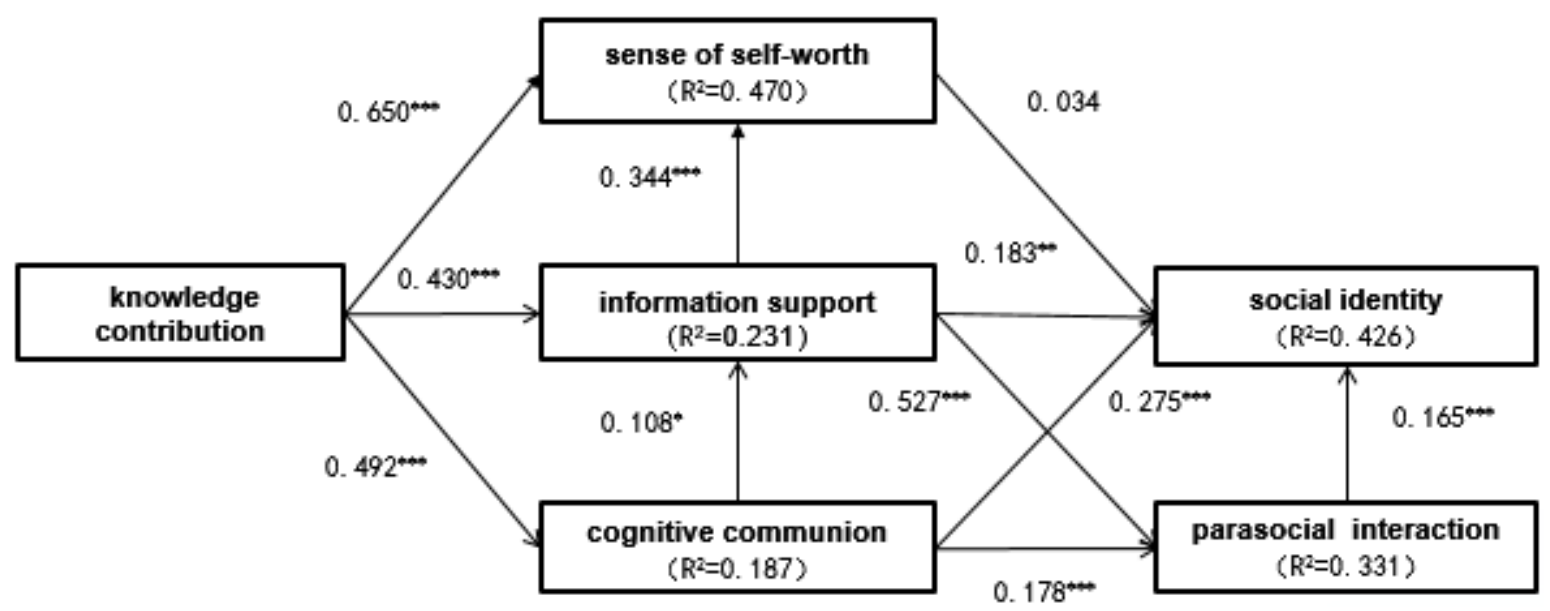

Figure 2. Model testing results. Notes: ${ }^{*} p<0.05 ;{ }^{* *} p<0.01 ;{ }^{* *} p<0.001$.

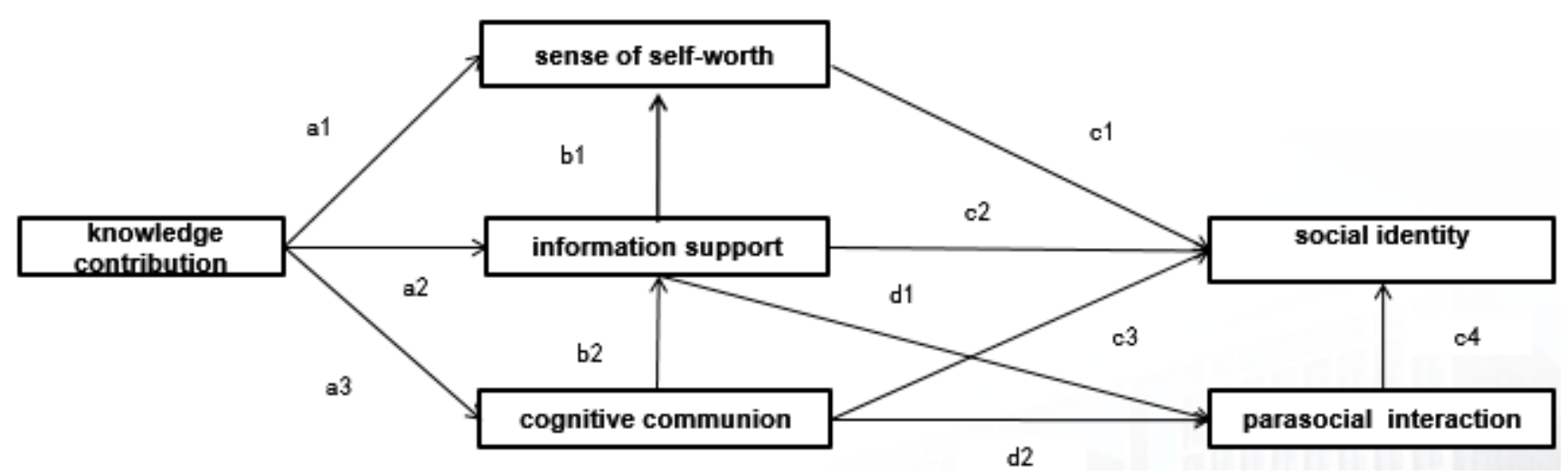

Figure 3. Mediation effect analysis model.

Table 5. Indirect effects of knowledge contribution on social identity through the sense of self-worth, parasocial interaction, cognitive communion, and information support.

\begin{tabular}{cccccc}
\hline & & \multicolumn{2}{c}{ Product of Coefficients } & \multicolumn{2}{c}{ Bootstrapping BC 95\% CI } \\
\hline & $\begin{array}{c}\text { Point } \\
\text { estimate }\end{array}$ & SE & $\mathrm{Z}$ & Lower limit & Upper limit \\
\hline $\mathrm{a} 1^{*} \mathrm{c} 1$ & 0.022 & 0.031 & 0.7097 & -0.033 & 0.090 \\
$\mathrm{a}{ }^{*} \mathrm{c} 2$ & 0.079 & 0.035 & 2.257 & 0.021 & 0.161 \\
$\mathrm{a} 3^{*} \mathrm{c} 3$ & 0.135 & 0.031 & 4.355 & 0.084 & 0.204 \\
$\mathrm{a} 2^{*} \mathrm{~b} 1^{*} \mathrm{c} 1$ & 0.005 & 0.007 & 0.7143 & -0.008 & 0.021 \\
$\mathrm{a} 2^{*} \mathrm{~d} 1^{*} \mathrm{c} 4$ & 0.037 & 0.015 & 2.467 & 0.014 & 0.077 \\
$\mathrm{a} 3^{*} \mathrm{~d} 2^{*} \mathrm{c} 4$ & 0.014 & 0.007 & 2.000 & 0.005 & 0.035 \\
$\mathrm{a} 3^{*} \mathrm{~b} 2^{*} \mathrm{c} 2$ & 0.010 & 0.006 & 1.667 & 0.001 & 0.026 \\
$\mathrm{a} 3^{*} \mathrm{~b} 2^{*} \mathrm{~b} 1^{*} \mathrm{c} 1$ & 0.001 & 0.001 & 1.000 & -0.001 & 0.004 \\
$\mathrm{a} 3^{*} \mathrm{~b} 2{ }^{*} \mathrm{~d} 1^{*} \mathrm{c} 4$ & 0.005 & 0.003 & 1.667 & 0.001 & 0.014 \\
\hline
\end{tabular}

$\mathrm{SE}=$ standard error, $\mathrm{BC}=$ bias corrected confidence intervals, 5000 bootstrap samples.

As presented in Table 5, there is a $95 \%$ likelihood that the indirect effects of a1 ${ }^{*} \mathrm{c} 1$ (knowledge contribution to social identity via the sense of self-worth), a $2^{*} \mathrm{~b}^{*} \mathrm{c} 1$ (knowledge contribution to social identity via information support and the sense of self-worth), and $\mathrm{a} 3^{*} \mathrm{~b} 2{ }^{*} \mathrm{~b} 1{ }^{*} \mathrm{c} 1$ (knowledge contribution to social identity via cognitive communion, information support and the sense of self-worth) are not significant because 0 occurs between the 
lower and upper limits. We can conclude that other specific indirect effects are significant because 0 is not included between the lower and upper limits.

\section{Discussion and Conclusions}

\subsection{General Discussion}

This research includes an in-depth exploration of the social and psychological outcomes of knowledge contribution and how the social identity of posters and lurkers arises from them in OKCs. This research constructs a model of the social identity formation path, which shows that cognitive communion, parasocial interaction, and information support play mediating roles between knowledge contribution and social identity. The social identity of posters and lurkers can be developed through the mediating effects of the above variables.

First, the social identity of the posters can be formed, based on knowledge contribution, through the mediating effects of information support and cognitive communication. Knowledge contribution has a significant impact on the formation of information support and cognitive communication. Factors such as personal views, experiences, and methods displayed by group members tend to attract the attention and responses of others; more knowledge contributions can stimulate more interaction among members and promote questions and answers among the group. In fact, information support is a significant component of knowledge contribution, and more knowledge contribution means more information support; there is a close relationship between knowledge contribution and information support, as shown by the path coefficient between them in the model, and the direct correlation coefficient between them reaches 0.43 . Information support can be seen as a typical manifestation of social identity at the behavioral level, which contributes to the generation of a sense of identity and belonging. The posters show their opinions or solve problems raised by others, which elicits social interaction. During this interaction, the posters can more easily find other group members with similar opinions, and the similarity between members facilitates the formation of mutual identification and close relationships, which indicates that knowledge contribution highly affects cognitive communication, as shown in Figure 2. The correlation coefficient between the two is as high as 0.492. Cognitive communication reflects the strength of the relationship between members: the higher the degree of cognitive communication, the closer the relationships among members. In social networks, perceived similarity generates interpersonal bonds, and the establishment of interpersonal bonds is an important pathway to reach a sense of belonging. In summary, information support and cognitive communication engage in mediating roles between knowledge contribution and social identity in OKCs, and the social identity of posters can be formed based on knowledge contribution through the social path in OKCs.

Second, the social identity of the poster cannot be formed through the mediating effect of the sense of self-worth. Because hypothesis $\mathrm{H} 2$ is not supported, the sense of self-worth has no significant effect on social identity, and this result is inconsistent with previous studies. Self-assessment factors play a very important role in the formation of social identity. People are very willing to belong to groups that bring them high self-esteem. The sense of self-worth comes from contribution behaviors, and the acquisition of self-worth predicts the generation of high self-esteem. The sense of self-worth has a deeper psychological effect hidden below high self-esteem, so a significant correlation exists between the sense of self-worth and social identity in other types of virtual communities. The possible reason for this anomaly is that the sense of self-worth comes from knowledge contribution, and members with more knowledge contribution may have a higher professional level within the group. Therefore, they may be more willing to lead rather than merely belong to the group. In general, the social identity of the posters cannot be formed through the psychological path in OKCs.

Third, the social identity of lurkers can be formed through the mediating effect of parasocial interaction. Information support and cognitive communication have a positive and significant impact on parasocial interaction. The values provided by OKCs mainly fall 
into three categories: functional value (knowledge contribution and information support), social value (cognitive communion), and psychological value (sense of self-worth, parasocial interaction, and social identity) [61]. Functional value is the foundation of the value system; therefore, if there is no functional value, members cannot be deeply involved in OKCs. The acquisition of social value depends on whether members actively interact with other members, while psychological value depends on the extent to which members can be closely related to the OKCs and evoke a certain emotional state in interaction [62]. The main purpose of members joining the OKCs is to obtain more accurate and valuable information; information support mainly meets the needs of those members for functional value. Cognitive communication meets the social needs of members [63], which can generate a strong sense of psychological participation when lurkers browse for information [64]. Thus, both information support and cognitive communication can facilitate parasocial interaction. The higher the lurkers' participation in parasocial interaction, the deeper their emotional attachment to other members and the stronger their sense of identity. In summary, the social identity of lurkers can be formed through a psychological path.

Fourth, personalized behaviors and social identity can coexist in OKCs. Social identity emphasizes consistency among group members, while personalized behaviors reflect the differences in behaviors among group members. Therefore, some studies suggest that personalized behaviors can hinder the integration of posters into the group and the formation of posters' social identity and can have a negative impact on the group. Because the content of knowledge contribution is personalized, knowledge contribution behavior is personalized behavior [30]. Personalized knowledge contribution behaviors can elicit a sense of belonging for posters via social and psychological satisfaction. The transformation process of personalized behaviors to social identity does not mean that personalized behaviors disappear but, rather, that social identity can be generated on the basis of personalized behaviors, allowing personalized behaviors and social identity to coexist.

\subsection{Theoretical Implications}

This study makes several theoretical contributions to both the online knowledge community literature and social identity formation research.

First, this study explored the social and psychological outcomes produced by knowledge contribution in OKCs. Some studies on knowledge contribution in VCs have previously suggested potential social and psychological motivations for knowledge contribution, including gaining prestige, relationship maintenance, reciprocity, and developing social relationships. However, these studies failed to reveal the deeper social and psychological factors hidden behind these motives. This study reveals deep social and psychological outcomes arising from knowledge contribution: parasocial interaction, cognitive communion, social identity, the sense of self-worth, and information support.

Second, this study constructs a complete path model of the social identity formation of posters and lurkers. Some studies indicate that there are many factors (i.e., knowledge contribution, parasocial interaction, cognitive communion, social identity, the sense of self-worth, and information support) that play a role in the formation of social identity; however, few studies have integrated these factors to form a complete path for social identity formation in OKCs. This study contributes to social identity formation research by exploring how and which factors establish the formation path of the social identity of posters and lurkers.

Third, this study reveals a more complete and in-depth relationship between personalized behavior (knowledge contribution) and social identity. Personalized behavior is often considered to be detrimental to the formation of social identity. However, through the transformation of several mediating variables, personalized behavior can significantly promote the formation of social identity in OKCs. This research comprehensively reveals the mechanism transforming individualized behavior into social identity, or the compatible mechanisms of the two, which led to the development of these related theories. 


\subsection{Practical Implications}

The path model of social identity formation, based on knowledge contribution, describes the social and psychological processes experienced by group members participating in online knowledge communities and reveals the self-operating and self-regulating mechanisms of online knowledge communities, providing an important reference basis for the management of online knowledge community operators.

From this research, it has been determined that, first, managers need to pay more attention to functional value, as it is the most important and fundamental value. Highquality posting content can generate interaction and discussion among members, making the community function properly in order to produce vibrant, high-quality content, which is the key to operating OKCs. Managers should ensure that high-quality content can be continuously generated by offering hot topics and novel perspectives. In addition, managers should encourage not only quality high-quality content sharers but also highquality questioners, as substantive questions can attract more professional members to answer, thus generating quality content.

Second, managers should promptly punish irrational postings that disrupt the order of the online knowledge community, such as removing irrational posters in good time and aiming to maintain an open and inclusive virtual community environment.

Third, lurkers make up the majority of the population in OKCs, so turning them into posters is necessary to maintain a vibrant and sustainable community. Managers should take the initiative to ask lurkers questions or make rules (i.e., if a member does not post for a sustained period of time, he or she will be removed from the community) to effectively turn lurkers into posters who engage in knowledge contribution.

Fourth, managers can encourage old members to introduce new members to online knowledge communities by giving incentives in the form of points or virtual title rewards. Managers can also invite well-known experts or opinion leaders in the industry into online knowledge communities, who will attract more new people to the virtual community through their reputations and professional knowledge contribution.

\subsection{Limitations and Future Research}

This research offers important theoretical and practical enlightenment, but it also has some limitations. The subjects of the questionnaire survey did not include all age levels, and the questionnaire was only surveyed in 3 OKCs. Future research can test the model of this research in other online knowledge communities to verify the universality of the theoretical model. Second, because the small amount of variance is explained, there may be other factors that have not been discovered, such as perceived benefits and perceived costs, which have an important impact on the psychology and behavior of group members. OKCs have become very popular in China, and participation in OKCs has become an indispensable part of many people's daily lives; thus, the psychological processes and behaviors of group members need to be further studied.

Author Contributions: Investigation, C.L.; Methodology, Z.C.; Writing—original draft, T.G. All authors have read and agreed to the published version of the manuscript.

Funding: This research was funded by [Beijing Social Science Foundation] grant number [16GLA007].

Institutional Review Board Statement: Participants were assured of data confidentiality and it was explained that only the authorized researchers could access the data. This study was conducted in compliance with the Helsinki Declaration, and was reviewed and approved by Center for Research in Organizational Behavior, Beihang University.

Informed Consent Statement: The protocol was approved by the Ethics Committee of 16GLA007.

Data Availability Statement: The data that support the findings of this study are available on request fron the corresponding author. The data are not publicly available due to privacy or ethical restrictions.

Conflicts of Interest: The authors declare no conflict of interest. 


\section{References}

1. Jin, J.; Li, Y.; Zhong, X.; Li, Z. Why users contribute knowledge to online communities: An empirical study of an online social and community. Inf. Manag. 2015, 52, 840-849. [CrossRef]

2. Park, D.H.; Lee, J. eWOM overload and its effect on consumer behavioral intention depending on consumer involvement. Electron. Commer. Res. Appl. 2008, 7, 386-398. [CrossRef]

3. Zheng, X.; Zhu, S.; Lin, Z. Capturing the essence of word-of-mouth for social commerce: Assessing the quality of online e-commerce reviews by a semi-supervised approach. Decis. Support Syst. 2013, 56, 211-222. [CrossRef]

4. Ye, H.J.; Feng, Y.; Choi, B. Understanding knowledge contribution in online knowledge communities: A model of community support and forum leader support. Electron. Commer. Res. Appl. 2015, 14, 34-45. [CrossRef]

5. Moser, C.; Deichmann, D. Knowledge Sharing in Two Cultures: The Moderating Effect of National Culture On Perceived Knowledge Quality In Online Communities. Eur. J. Inf. Syst. 2020, 30, 623-641. [CrossRef]

6. Wasko, M.L.; Teigland, R.; Faraj, S. The provision of online public goods: Examining social structure in an electronic network of practice. Decis. Support Syst. 2009, 47, 254-265. [CrossRef]

7. Lai, H.M.; Chen, T.T. Knowledge sharing in interest online communities: A comparison of posters and lurkers. Comput. Hum. Behav. 2014, 35, 295-306. [CrossRef]

8. Kim, J. "I Want to be Different from Others in Cyberspace” The Role of Visual Similarity in Virtual Group Identity. Comput. Hum. Behav. 2009, 25, 88-95. [CrossRef]

9. Chiu, C.M.; Hsu, M.H.; Wang, E. Understanding Knowledge Sharing in Virtual Communities: An Integration of Social Capital and Social Cognitive Theories. Decis. Support Syst. 2006, 42, 1872-1888. [CrossRef]

10. Spears, R. Social Influence and Group Identity. Annu. Rev. Psychol. 2021, 72, 367-390. [CrossRef]

11. Lin, H.F. Determinants of Successful Virtual Communities: Contributions from System Characteristics and Social Factors. Inf Manag. 2008, 45, 522-527. [CrossRef]

12. Jans, L.; Postmes, T.; Vander Zee, K. Sharing differences: The inductive route to social identity formation. J. Exp. Soc. Psychol. 2012, 48, 1145-1149. [CrossRef]

13. Coleman, J. Social Capital in the Creation of Human Capital. Am. J. Sociol. 1988, 94, 95-120. [CrossRef]

14. Lee, D.; Borah, P. Self-presentation on instagram and friendship development among young adults: A moderated mediation model of media richness, perceived functionality, and openness. Comput. Hum. Behav. 2020, 103, 57-66. [CrossRef]

15. Gosnell, C.L.; Britt, T.W.; Mckibben, E.S. Self-Presentation in Everyday Life: Effort, Closeness, and Satisfaction. Self Identity 2011, 10, 18-31. [CrossRef]

16. Duffy, M.K.; Stark, S. Performance and satisfaction in conflicted interdependent groups: When and how does self-esteem make a difference? Acad. Manag. J. 2000, 43, 772-782. [CrossRef]

17. Casaló, L.V.; Carlos, F.; Sergio, I.S. Influencers on instagram: Antecedents and consequences of opinion leadership. J. Bus. Res. 2018, 117, 510-519. [CrossRef]

18. Wang, X.L.; Lu, J.D.; Ow, T.T.; Feng, Y.Q.; Liu, L.N. Understanding the emotional and informational influence on customer knowledge contribution through quantitative content analysis. Inf. Manag. 2021, 58, 103426. [CrossRef]

19. Tajfel, H. Social psychology of intergroup relations. Annu. Rev. Psychol. 1982, 33, 1-39. [CrossRef]

20. Turner, J.C. Social comparison and social identity: Some prospects for intergroup behaviour. Eur. J. Soc. Psychol. 1975, 5, 5-34. [CrossRef]

21. Ellemers, N.; Kortekaas, P.; Ouwerkerk, J.W. Self-Categorisation, Commitment to the Group and Group Self-Esteem as Related but Distinct Aspects of Social Identity. Eur. J. Soc. Psychol. 1999, 29, 371-389. [CrossRef]

22. Chang, H.H.; Chuang, S.S. Social capital and individual motivations on knowledge sharing: Participant involvement as a moderator. Inf. Manag. 2011, 48, 9-18. [CrossRef]

23. Granovetter, M.S. Economic action and social structure: The problem of embeddedness. Am. J. Sociol. 1985, 91, 481-510. [CrossRef]

24. Ashforth, B.E.; Mael, F. Social identity theory and the organization. Acad. Manag. Rev. 1989, 14, 20-39. [CrossRef]

25. Lea, M.; Spears, R.; de Groot, D. Knowing me, knowing you: Anonymity effects on social identity processes within groups. Personal. Soc. Psychol. Bull. 2001, 27, 526-537. [CrossRef]

26. Wallace, H.M.; Baumeister, R.F. The performance of narcissists rises and falls with perceived opportunity for glory. J. Personal. Soc. Psychol. 2002, 82, 819-834. [CrossRef]

27. Wojcieszak, M. What Predicts Selective Exposure Online: Testing Political Attitudes, Credibility, and Social Identity. Commun. Res. 2021, 48, 687-716. [CrossRef]

28. Chuang, Y.W. Promoting Consumer Engagement in Online Communities through Virtual Experience and Social Identity. Sustainability 2020, 12, 855. [CrossRef]

29. Ashforth, B.E.; Harrison, S.H.; Corley, K.G. Identification in organizations: An examination of four fundamental questions. J. Manag. 2008, 34, 325-374. [CrossRef]

30. Drury, J. The role of social identity processes in mass emergency behaviour: An integrative review. Eur. Rev. Soc. Psychol. 2018, 29, 38-81. [CrossRef]

31. Ma, W.W.K.; Yuen, A.H.K. Understanding online knowledge sharing: An interpersonal relationship perspective. Comput. Educ. 2011, 56, 210-219. [CrossRef] 
32. Wu, C.C.; Chiang, L.C. Relationships between User Knowledge Sharing in Virtual Community with Community Loyalty and Satisfaction. Psychol. Res. Behav. Manag. 2021, 14, 1509-1523.

33. Cheng, Z.C.; Guo, T.C. the formation of social identity and self-identity based on knowledge contribution in virtual communities: An inductive route model. Comput. Hum. Behav. 2015, 43, 229-241. [CrossRef]

34. Zhou, T.; Li, H. Understanding mobile SNS continuance usage in China from the perspectives of social influence and privacy concern. Comput. Hum. Behav. 2014, 37, 283-289. [CrossRef]

35. Horton, D.; Wohl, R.R. Mass communication and para-social interaction: Observations on intimacy at a distance. Psychiatry 1956, 19, 215-229. [CrossRef]

36. Dibble, J.L.; Hartmann, T.; Rosaen, S.F. Parasocial interaction and parasocial relationship: Conceptual clarification and a critical assessment of measures. Hum. Commun. Res. 2016, 42, 21-44. [CrossRef]

37. Hajli, N.; Shanmugam, M.; Powell, P.; Love, P.A. study on the continuance participation in on-line communities with social commerce perspective. Technol. Forecast. Soc. Change 2015, 96, 232-241. [CrossRef]

38. Hsu, L.C.; Chih, W.H.; Liou, D.K. Understanding community citizenship behavior in social networking sites an extension of the social identification theory. Ind. Manag. Data Syst. 2015, 115, 1752-1772. [CrossRef]

39. Rink, F.; Ellemers, N. Diversity as a basis for shared organizational identity: The norm congruity principle. Br. J. Manag. 2007, 18, 17-27. [CrossRef]

40. Chou, S.W.; Min, H.T.; Chang, Y.C.; Lin, C.T. Understanding continuance intention of knowledge creation using extended expectation-confirmation theory: An empirical study of Taiwan and China online communities. Behav. Inf. Technol. 2010, 29, 557-570. [CrossRef]

41. Pierce, J.L.; Gardner, D.G. Self-esteem within the work and organizational context: A review of the organization-based self-esteem literature. J. Manag. 2004, 30, 591-622. [CrossRef]

42. Rousseau, D.M. Why Workers Still Identify with Organizations. J. Organ. Behav. 1998, 19, 217. [CrossRef]

43. Kuss, D.J.; Griffiths, M.D. Online Social Networking and Addiction-A Review of the Psychological Literature. Int. J. Environ. Res. Public Health 2011, 8, 3528-3552. [CrossRef] [PubMed]

44. Elsayed, W. The negative effects of social media on the social identity of adolescents from the perspective of social work. Heliyon 2021, 7, e06327. [CrossRef]

45. Lozano-Blasco, R.; Pilar Latorre-Martinez, M.P.; Cortes-Pascual, A. Analizing Teens an Analysis from the Perspective of Gamers in Youtube. Sustainability 2021, 13, 11391. [CrossRef]

46. Ren, Y.; Harper, F.M.; Drenner, S.; Terveen, L.; Kraut, R.E. Building Member Attachment in Online Communities: Applying Theories of Group Identity and Interpersonal Bonds. Manag. Inf. Syst. Q. 2012, 36, 841-864. [CrossRef]

47. Hargittai, E.; Litt, E. The tweet smell of celebrity success: Explaining variation in Twitter adoption among a diverse group of young adults. New Media Soc. 2011, 13, 824-842. [CrossRef]

48. Hoof, B.; Rideer, J. Knowledge sharing in context: The influence of organizational commitment communication climate and CMC use on knowledge sharing. J. Knowl. Manag. 2004, 8, 117-130. [CrossRef]

49. Lim, S.; Cha, S.Y.; Park, C.; Lee, I.; Kim, J. Getting closer and experiencing together: Antecedents and consequences of psychological distance in social media- enhanced real-time streaming video. Comput. Hum. Behav. 2012, 28, 1365-1378. [CrossRef]

50. Bock, G.W.; Zmud, R.W.; Kim, Y.G.; Lee, J.N. Behavioral intention formation in knowledge sharing: Examining the roles of extrinsic motivators, social-psychological forces, and organizational climate. MIS Q. 2005, 29, 87-112. [CrossRef]

51. Swaab, R.I.; Postmes, T.; Beest, I.V.; Spears, R. Shared Cognition as a Product of, and Precursor to, Shared Social Identity: Studying the Role of Communication in Negotiations. Personal. Soc. Psychol. Bull. 2003, 33, 187-199. [CrossRef] [PubMed]

52. Hajli, M.N. The role of social support on relationship quality and social commerce. Technol. Forecast. Soc. Change 2014, 87, 17-27. [CrossRef]

53. Lindell, M.K.; Whitney, D.J. Accounting for common method variance in cross-setonol research designs. J. Appl. Psychol. 2001, 86, 114-121. [CrossRef] [PubMed]

54. Malhotra, N.K.; Kim, S.S.; Patil, A. Common method variance in IS research: A comparison of alternative approaches and a reanalysis of past research. Manag. Sci. 2006, 52, 1865-1883. [CrossRef]

55. Podsakoff, P.; MacKenzie, S.; Lee, J.; Podsakoff, N. Common method biases in behavioral research: A critical review of the literature and recommended remedies. J. Appl. Psychol. 2003, 88, 879-903. [CrossRef]

56. Zhao, L.; Lu, Y.b.; Wang, B.; Chau, P.Y.K.; Zhang, L. Cultivating the sense of belonging and motivating user participation in virtual communities: A social capital perspective. Int. J. Inf. Manag. 2012, 32, 574-588. [CrossRef]

57. Bagozzi, R.P.; Yi, Y. On the evaluation of structural equation models. J. Acad. Mark. Sci. 1988, 16, 74-94. [CrossRef]

58. King, W.R.; Teo, T.S.H. Key dimensions of facilitators and inhibitors for the strategic use of information technology. J. Manag. Inf. Syst. 1996, 12, 35-53. [CrossRef]

59. Browne, M.W.; Cudeck, R. Alternative ways of assessing model fit. In Testing Structural Equation Models; Bollen, K.A., Long, J.S., Eds.; Sage: Newbury Park, CA, USA; pp. 136-162.

60. Preacher, K.J.; Hayes, A.F. Asymptotic and resampling strategies for assessing and comparing indirect effects in multiple mediator models. Behav. Res. Methods 2008, 40, 879-891. [CrossRef]

61. Kim, H.W.; Gupta, S.; Koh, J. Investigating the intention to purchase digital items in social networking communities: A customer value perspective. Inf. Manag. 2011, 48, 228-234. [CrossRef] 
62. Huang, A.H.; Yen, D.C.; Zhang, X. Exploring the potential effects of emoticons. Inf. Manag. 2008, 45, 466-473. [CrossRef]

63. Badrinarayanan, V.A.; Sierra, J.J.; Martin, K.M. A dual identification framework of online multiplayer video games: The case of massively multiplayer online role playing games (MMORPGs). J. Bus. Res. 2015, 68, 1045-1052. [CrossRef]

64. Luo, N.; Zhang, M.; Liu, W. The effects of value co-creation practices on building armonious brand community and achieving brand loyalty on social media in China. Comput. Hum. Behav. 2015, 48, 492-499. [CrossRef] 